\title{
Abundance and Distribution Patterns of Megadrilli Earthworms at Different Altitude in Kabawetan Tea Plantation, Bengkulu
}

\author{
Darmi $^{1{ }^{1 *}}$ Rizwar $^{1}$ Helmiyetti ${ }^{1}$ \\ ${ }^{1}$ Biology Department, Faculty of Mathematics and Natural Science, Bengkulu University, W.R. Supratman \\ Street, Bengkulu City. Post code 38371, Phone (0736)-20919 \\ *Corresponding author.Email: darmi@unib.ac.id
}

\begin{abstract}
Earthworms are an important component of natural and agricultural land ecosystems. The existence of earthworms in agricultural land can increase soil fertility and also support a sustainable agricultural system. This study aims to determine the abundance and distribution patterns of megadrilli earthworms in the Bengkulu Kabawetan Tea Plantation. Determination of the research location used the stratified sampling method which consisted of altitude strata, namely an altitude of 800, 900, and 1000 meters above sea level. The samples of earthworms were taken using the quadratic method $(30 \times 30 \times 20 \mathrm{~cm})$ and the hand sorting method as many as 15 plots for each location. The data were analyzed for population densities and distribution patterns using the Morisita Index formula. The results showed that only one species of megadrilli earthworm was found Pontoscolex corethrurus in tea plantations. The highest earthworm population density was at a location of 1000 $\mathrm{m}$ above sea level ( 89.66 individuals $\mathrm{m}^{-2}$ ), followed by a location of $900 \mathrm{~m}$ (70.33 individuals $\mathrm{m}^{-2}$ ), and the lowest density was at a location of $800 \mathrm{~m}$ (24.44 individuals $\left.\mathrm{m}^{-2}\right)$. Statistically, it showed that the densities of the earthworm population at an altitude of $1000 \mathrm{~m}$ and $900 \mathrm{~m}$ were not significantly different, but it was significantly different from an altitude of $800 \mathrm{~m}$. The distribution pattern of megadrilli earthworms based on the Morisita Index value showed that the three locations have a clustered pattern.
\end{abstract}

Keywords: Density, Distribution Patterns, Megadrilli Earthworms, Tea Plantation

\section{INTRODUCTION}

Earthworms belong to the terrestrial Oligochaeta group, which are generally divided into 2 groups, namely Megadrilii and Microdrilli. The difference between the two groups is based on body size, megadrilli worms are included in the soil macrofauna group (diameter $>2 \mathrm{~mm}$ and length $>4$ $\mathrm{mm}$ ), while microdrilli belongs to the soil mesofauna group (0.2-2 mm). Megadrilli worms are often referred to as earthworms [1-3].

Earthworms are an important component in the soil ecosystem and are often referred to as ecosystem engineers which play an important role in the process of soil formation from both physical and chemical properties [4]. Physically, earthworms can increase soil infiltration and aeration, and chemically play a role in the decomposition of soil organic matter and the nutrient cycle. The existence of earthworms in a habitat provides many benefits to soil quality and health because earthworms contribute to increasing soil fertility [5-7]. According to Frund's [8], earthworms can show soil quality through data on abundance, diversity, and activities in the soil, such as preference, burrow formation, and manure production.

Earthworms can live in various terrestrial ecosystems both in natural ecosystems (forests, shrubs) and artificial ecosystems (agricultural land, plantations, carpets, etc.). The existence of earthworms in their habitat is often unevenly distributed, depending on many factors such as vegetation, soil texture, and their dietary preferences for soil organic matter $[9,10]$. The abundance of the earthworm population varies in different habitats. Research results by Sabrina's [11] showed that the highest earthworm population density in oil palm plantations in Malaysia was 42 individuals. $\mathrm{m}-2$, 
research by Darmi's [12], the highest density of earthworm populations in peatlands planted with oil palm in Bengkulu (Indonesia) was 35 individual m-2. In rubber plantations in India, the highest density is 78 individuals.m-2 [13].

Previous research on earthworm populations in plantation land includes Earthworm population of rubber plantations (Hevea brasiliensis) in Tripura, India [13], Earthworm population, and cast properties in the soils of oil palm plantations [11], Abundance and distribution pattern of earthworm in peatland planted with different ages of oil palm plantation in the district of Seluma, Bengkulu province [12], Earthworm populations in Eucalyptus spp. Plantations at Embrapa Forestry, Brazil [14], Landuse change on Mount Gede, Indonesia, reduced native earthworm populations and diversity [16], Earthworm community structure under tea plantations in Tripura, India [17]

Changes in land use into plantation land have an impact on soil biota, including earthworms. The results of research by Darmawan's [16] show that changing land use to mixed plantations and annual agriculture has reduced the diversity of earthworms in the Mount Gede area, Indonesia.

Tea plantation is a form of conversion of forest land into agricultural land. With the application of monoculture systems and agricultural technology in tea plantations, the totality of biotic and abiotic environmental factors has changed from the original ecosystem, including the earthworm community. The presence of earthworms in agricultural land or plantation land is an important component in maintaining the balance of the ecosystem and can improve soil quality. The earthworm's activity helps maintain the sustainability of the agroecosystem and also the sustainability of the agricultural system on plantation land. So far there is still little information about the ecological aspects of earthworms in tea plantations, so it is necessary to research the abundance and distribution patterns of megadrilli earthworms in the tea plantation areas of Kabawetan Bengkulu. This study aims to analyze the ratio of abundance and distribution patterns of megadrilli earthworms based on altitude in the tea plantation.

\section{METHODOLOGY}

This research was conducted in Bengkulu Kabawetan Tea Plantation and continued in the Biology Laboratory of Faculty of Mathematics and Natural Sciences, Bengkulu University from September to November 2019. The research location was determined using the stratified sampling method which consists of altitude strata, namely an altitude of 800, 900, and $1000 \mathrm{~m}$ above sea level. Earthworms were taken using the quadratic method $(30 \times 30 \times 20$ $\mathrm{cm}$ ) and the hand sorting method. At each location, a horizontal transect line was made $100 \mathrm{~m}$ long and along the transect, a systematic plot of 15 plots was made. Earthworms were collected using the hand sorting method and preserved with $4 \%$ formalin. Identification and counting of the number of individual earthworms were carried out at the Biology Laboratory of the University of Bengkulu. The parameters studied in this study were population density and the distribution pattern of megadrilli earthworms. Abiotic factors were also measured at each location, namely soil temperature, soil moisture, soil $\mathrm{pH}$, and soil organic content. Soil temperature measurements are carried out directly in the field using a soil thermometer, soil $\mathrm{pH}$ is measured with a soil tester, while the measurement of soil moisture and organic content uses the gravimetric method by taking soil samples from the field for analysis in the laboratory. Earthworm data were analyzed for density [18] (abundance) and Morisita Index [19] using the following formula:

Density $=\frac{\text { individuals number of species }}{\text { per total number of samples }}$

To determine the significance of differences in earthworm populations in the three altitude strata, the Analysis of Variance (ANOVA) and Duncan's continued test was carried out using the SPSS program.

Indeks Morisita:

$\mathrm{Id}=\mathrm{n} \frac{\sum \mathrm{x}^{2}-\mathrm{N}}{\mathrm{N}(\mathrm{N}-1)}$

The Morisita Index value obtained is followed by the Chi-squared test $\left(\mathrm{X}^{2}\right)$ to determine its significance or truth, with the following formula:

Chi - square $\left(X^{2}\right)=\frac{n \sum_{x} 2}{N}-N$

\section{Note:}

$\mathrm{n}=$ number of plots

$\mathrm{N}=$ total number of individuals in $\mathrm{n}$ plots

$\sum X 2=$ square of the number of individuals per plot

Id $<1$ (uniform distribution)

Id $=1$ (random distribution)

Id $>1$ (clustered distribution 
Furthermore, the calculated Chi-squared value (calculated $\mathrm{X}^{2}$ ) was compared with the calculated Chi-squared value ( $\mathrm{X}^{2}$ table) at the $95 \%$ confidence level (0.05). If the calculated $X^{2}$ value $<X^{2}$ table, the distribution pattern is random, on the other hand, if the calculated $\mathrm{X}^{2}$ value $>\mathrm{X}^{2}$ table, the result shows that the distribution pattern is significantly different from random, which means that the distribution pattern is clustered.

\section{RESULTS AND DISCUSSION}

The results showed that only one type of megadrilli earthworm was obtained, namely Pontoscolex corethrurus (Table). P. Corethrurus worm is an exotic species that is widespread in various countries 20. Several previous studies also found that only $P$. Corethrurus species on plantation land were researched by Sabrina's [11] in Malaysian oil palm plantations, research by Darmi's [12] on peatlands planted with oil palm in Bengkulu (Indonesia). Only $P$. corethrurus was found in tea plantations, related to the application of the monoculture farming system to tea

Table 1. Population Densities of Megadrilli Earthworms at Altitude Different in Bengkulu Kabawetan Tea Plantation

\begin{tabular}{ccccc}
\hline No & $\begin{array}{c}\text { Altitude } \\
\text { of } \\
\text { Location }\end{array}$ & $\begin{array}{c}\text { Species of } \\
\text { earthworm } \\
\text { megadrilli }\end{array}$ & $\begin{array}{c}\text { Density } \\
\text { individu } \\
\text { als. }\left(\mathbf{m}^{-2}\right)\end{array}$ & Notation \\
\hline 1 & $800 \mathrm{~m}$ & $\begin{array}{c}\text { Pontoscolex } \\
\text { corethrurus }\end{array}$ & 24,4 & $\mathrm{a}$ \\
2 & $900 \mathrm{~m}$ & $\begin{array}{c}\text { Pontoscolex } \\
\text { corethrurus }\end{array}$ & 70,33 & $\mathrm{~b}$ \\
3 & $1000 \mathrm{~m}$ & $\begin{array}{c}\text { Pontoscolex } \\
\text { corethrurus }\end{array}$ & 86,66 & $\mathrm{~b}$ \\
\hline
\end{tabular}

Note: Number followed by the same letter indicates no significant difference $(\mathrm{p}<0.05)$.

plantations and the lack of basic vegetation on the ground due to dense canopy cover and land clearing activities from weeds. As an exotic species, including $P$. corethrurus, it has high adaptability, so it can develop well and eliminate local earthworms.

Earthworm population densities varied at each study location. The highest density is at an altitude location of $1000 \mathrm{~m}$ (86.66 individuals. $\left.\mathrm{m}^{-2}\right)$, followed by an altitude location of $900 \mathrm{~m}$ (70.33 individuals. $\mathrm{m}^{-2}$ ) and $800 \mathrm{~m}$ (24.44 individuals. $\mathrm{m}^{-2}$ ). Statistically, the abundance of the megadrilli earthworm population at the $1000 \mathrm{~m}$ and $900 \mathrm{~m}$ locations was not significantly different, but significantly different from the $800 \mathrm{~m}$ location. The highest population density of $P$. corethrurus earthworm (86.66 individuals. $\mathrm{m}^{-2}$ ) was obtained in the results of this study, which was much higher than previous studies. The results of Sabrina's [11] research on oil palm plantations in Malaysia, the highest density of $P$. corethrurus pollution was 42 individuals. $\mathrm{m}^{-2}$ and Darmi's [12] on peatland planted with oil palm in Bengkulu (Indonesia), the highest population density of $P$. corethrurus was 35 individuals. $\mathrm{m}^{-2}$. Besides, several studies have also shown that in general, the presence of $\mathrm{P}$. corethrurus earthworms is almost always dominant in the plantation or agricultural land [14-15].

The high population density of $P$. corethrurus earthworms in tea plantations at an altitude of 1000 meters is related to abiotic factors such as organic content and higher soil moisture compared to locations at an altitude of 900 and $800 \mathrm{~m}$ (Table 2). The availability of soil organic material is important for earthworms as saprophage animals, which are a source of food for earthworms. The results of research by Nurhidayati's [21] in sugarcane plantations in East Java (Indonesia) showed that the value of soil organic particles as an indicator of soil quality was also supported by high abundance data on earthworm

Table 2. The abiotic Factors at Different Altitude in Kabawetan Tea Plantation Bengkulu

\begin{tabular}{llccc}
\hline No & $\begin{array}{l}\text { The abiotic } \\
\text { Factors }\end{array}$ & $\begin{array}{c}\mathbf{8 0 0} \text { m alt } \\
(\mathbf{m e a n} \pm \text { SD })\end{array}$ & $\begin{array}{c}\mathbf{9 0 0} \text { m alt } \\
(\mathbf{m e a n} \pm \text { SD) }\end{array}$ & $\begin{array}{c}\mathbf{1 0 0 0} \text { m alt } \\
(\mathbf{m e a n} \pm \text { SD) }\end{array}$ \\
\hline 1 & $\begin{array}{l}\text { Soil } \\
\text { temperature } \\
\left({ }^{\circ} \mathrm{C}\right)\end{array}$ & $24,67 \pm 0,58$ & $24,33 \pm 0,58$ & $23,67 \pm 1,16$ \\
2 & $\begin{array}{l}\text { Soil } \\
\text { moisture } \\
(\%)\end{array}$ & $35,39 \pm 0,87$ & $41,43 \pm 0,68$ & $41,57 \pm 0,25$ \\
3 & $\begin{array}{l}\text { Soil } \\
\text { organic } \\
\text { matter }(\%)\end{array}$ & $1,66 \pm 0,32$ & $2,48 \pm 0,25$ & $3,02 \pm 0,33$ \\
4 & Soil pH & $6,77 \pm 0,06$ & $6,6 \pm 0,17$ & $6,7 \pm 0,17$ \\
\hline
\end{tabular}

populations. In addition to the high population of earthworms in tea plantations, it is possible that earthworms like organic material from tea leaves. The results of the research by Hitinayake's [22], also stated that the material from tea leaf waste was classified as a good material for earthworm maintenance media and could produce high-quality vermicompost. 
The results of the Morisita index (Id) analysis show that the three research locations have more than one score (Table 3). After doing the Chi squared test, it shows that the calculated Chi square (X2) value is greater than the Chi squared table at the three research locations. This means that the distribution pattern of $P$. corethrurus earthworms at the three research locations is grouped.

The distribution pattern of earthworms is closely related to the distribution of soil organic matter. The uneven distribution of organic material in a waste habitat is in the distribution pattern of earthworms. In general, in natural conditions, earthworms show a clustered distribution pattern [9]. Barois's [9], also states that distribution analysis using Taylor's Index also shows the spatial distribution of aggregated (clustered) earthworms. The results of research by Singh's [23] showed that abiotic factors such as $\mathrm{pH}$, humidity, soil texture, and soil organic $\mathrm{C}$ content had a significant effect on the distribution of earthworms. correlation with humidity and vegetation type. Darmi's [12] research on peatlands planted with oil palm, also shows the distribution pattern of the earthworm $P$. corehtrurus which is also clustered.

Table 3. Distribution Patterns of Macrodrilli Earthworms at an Altitude Different in Bengkulu Kabawetan Tea Plantation

\begin{tabular}{lccc}
\hline No & $\begin{array}{c}\text { Altitude of } \\
\text { Location }\end{array}$ & $\begin{array}{c}\text { Morisita } \\
\text { Index }\end{array}$ & $\begin{array}{c}\text { Distribution } \\
\text { Pattern }\end{array}$ \\
\hline 1 & $800 \mathrm{~m}$ & 2,08 & Clustered \\
2 & $900 \mathrm{~m}$ & 1,45 & Clustered \\
3 & $1000 \mathrm{~m}$ & 1,11 & Clustered \\
\hline $\begin{array}{l}\text { Note: } \\
\text { Id }=0 \text { or < } 1 \text { (uniform pattern) } \\
\text { Id }=1 \text { (random pattern) } \\
\text { Id }>1 \text { (clustered pattern) }\end{array}$ & & \\
\end{tabular}

\section{CONCLUSION}

The results showed that only one species of megadrilli earthworm was found Pontoscolex corethrurus in tea plantation Bengkulu District. The highest earthworm population density was at a location of $1000 \mathrm{~m}$ above sea level (89.66 individuals $\mathrm{m}-2)$, followed by a location of $900 \mathrm{~m}$ (70.33 individuals $\mathrm{m}-2$ ), and the lowest density was at a location of $800 \mathrm{~m}$ (24.44 individuals $\mathrm{m}-2)$. Statistically, it showed that the densities of the earthworm population at an altitude of $1000 \mathrm{~m}$ and $900 \mathrm{~m}$ were not significantly different, but it was significantly different from an altitude of $800 \mathrm{~m}$. The distribution pattern of megadrilli earthworms based on the Morisita Index value showed that the three locations have a clustered pattern.

\section{REFERENCES}

[1] A.H. Kemas, A. Napoleon, N. Ghofar, Soil biology, Ecology and Soil microbiology, PT Raja Grafindo, Jakarta, 2010.

[2] P. Lavelle, T. Decaens, M. Aubert, S. Barro, M. Blouin, Soil invertebrates and ecosystem service. European Journal of Soil Biology 42 (2006) S3-S15.

[3] M.J.N. Okwakol, M.B.Sekamatte, Soil macrofauna research in ecosystems in Uganda. African Journal of Ecology 45(2) (2007) 2-8.

[4] D.C. Coleman, D.A. Crossley, P.F. Hendrix, Fundamentals of soil ecology, Second Edition, Elsevier Academic Press, California, 2004.

[5] P. Lavelle, A.V. Spain, Soil Ecology, Kluwer Academic Publishers, New York, 2003.

[6] Y. Kavdir, R. Ilay, Earthworms and soil structure, in Soil Biology: Biology of Earthworm, Springer Heidelberg Dordrecht, London, New York, 2011.

[7] Husamah, A. Rahardjanto, A.M. Hudha, Soil animal ecology, UMM Press, Malang, 2017. [

[8] H.C. Frund, U. Graefe, S. Tischer, Earthworms as bioindicators of soil quality, In book: Biology of Earthworm (pp. 261-278), Springer-Verlag Publisher, Berlin, 2010.

[9] I. Barois, P. Lavelle, M. Brossard, E. J. Tondoh, Ecology of earthworm species with large environmental tolerance and/or extended distributions, In book: Earthworm management in tropical agroecosystems (pp. 5785), Edition 1, CAB International Publishing, London, 1999.

[10] N.M. Suin, Soil animal ecology, Fourth editon, Bumi Aksara \& Pusat Antar Universitas Ilmu Hayati ITB, Bandung, 2012.

[11] D.T. Sabrina, M.M. Hanafi, A.A. Nor Azwady, T.M.M. Mahmud, Earthworm populations and cast properties in the soils of oil palm plantations. Malaysian Journal of Soil Science 13 (2009) 29-42. 
[12] Darmi, D. Budianta, Sabaruddin, M.R. Rhido, Abundance and distribution pattern of earthworm in peatland planted with different age of oil palm plantation in the district of Seluma, Bengkulu Province, Asian Academic Research Journal of Multidisciplinary 1(22) (2014) 23192801.

[13] P.S. Chaudhuri, N. Sabyasachi, R. Paliwal, Earthworm population of rubber plantations (Hevea brasiliensis) in Tripura, India, Tropical Ecology 49 (2) (2008) 225-234.

[14] W. Maschio, F.M. Vezzani, G.G. Brown, Earthworm populations in Eucalyptus spp. plantations at Embrapa Forestry, Brazil (Oligochaeta), Proceedings 01 the 6th International Oligochaete Taxonomy Meeting (6th IOTM), Palmeira de Faro, Portugal, 22-25 April 2013, ISBN 9783-925064-69-2 (C) Kasparek Verlag, Heidelberg, 2013.

[15] P.S. Chaudiri, D.A. Battacharjee, S. Chattopadhyay, D. Bhattacharya, Impact of age of rubber (Hevea brasiliensis) plantation of earthworm communities of West Tipura (India), Journal of Environmental Biology 34 (2013) 5965.

[16] A. Darmawan, T. Atmowidi, W. Manalu, B. Suryobroto, Pontoscolex corethrurus (Müller, 1857), Linking Earthworm and Soil Mineral Content. International Journal of Sciences: Basic and Applied Research (IJSBAR) 29(2) (2016) 16-22.

[17] S.K.S. Jamatia, P.S. Chaudhuri, Earthworm community structure under tea plantations (Camellia sinensis) of Tripura (India), Tropical Ecology 58(1) (2017) 105-115.

[18] J.A. Wallwork, The distribution and diversity of soil fauna. Acad. Press. London, 1976.

[19] A. Soegianto, Quantitative ecology: Population analysis method and Community. Usaha Nasional, Surabaya, 1994.

[20] R. Marichal, A.F. Martinez, C. Praxedes, D. Ruiz, Invasion of Pontoscolex corethrurus (Glossoscolecidae, Oligochaeta) in landscapes of the Amazonian deforestation arc. Applied Soil Ecology 46 (2010) 443-449.

[21] Nurhidayati, E. Arisoesilaningsih, D. Suprayogo, K. Hairiah, Particulate organic matter as a soil quality indicator of sugarcane plantations in East Java. Agrivita 4(2) (2012) 175-185.

[22] H.M.G.S.B. Hitinayake, K.G.K.C. Ubayapala, J.K.S. Samaranayake, Evaluation of earthworm species and bedding material collected from tea plantation for vermicomposting in Sri Langka. International Journal of Environment, Agriculture and Biotechnology (IJEAB) 3(5) (2018) 1935-1939.

[23] S. Singh, J. Singh, A. Pal Vig, Effect of the abiotic factor on the distribution of earthworm in different land-use patterns, The Journal of Basic \& Applied Zoology 74 (2016) 41-50. 